\title{
DAMPAK FAKTOR EKSTERNAL DAN INTERNAL TERHADAP FINANCIAL DISTRESS PERUSAHAAN MANUFAKTUR GO PUBLIC SUBSEKTOR MAKANAN DAN MINUMAN TAHUN 2008-2017
}

\author{
EXTERNAL AND INTERNAL FACTORS IMPACT ON FINANCIAL DISTRESS \\ OF PUBLIC COMPANIES IN THE FOOD AND BEVERAGE SUBSECTOR FOR YEAR 2008-2017
}

\author{
Raditya Arie Priadi ${ }^{*}$, Bonar M Sinaga*), dan Trias Andati**) \\ *) Sekolah Bisnis, IPB University \\ Jl. Raya Pajajaran, Bogor 16151 \\ **) PT Adhimix Precast Indonesia \\ Jl. Raya Ps. Minggu No. 17 A, Pancoran Jakarta Selatan 12780
}

\begin{abstract}
The food and beverage sub-sector is a manufacturing sub-sector with the largest contribution and growth rate in Indonesia. This industry is important for the national economy. However, the business actors in this industry face difficulties due to a weak macroeconomic condition. Hence, public companies in the food and beverage sub-sector are vulnerable to financial distress. The research objective was to analyze external and internal factors impact on financial distress of public companies in the food and beverage subsector. The financial distress model used the form of a recursive equation system to evaluate the food and beverage sub-sector. We observed five companies that experienced financial difficulties such as AISA, CEKA, INDF, PSDN, and STTP. The results showed that a good external factor as a proxy for financial distress was not able to increase the debt service coverage ratio. We recommended that companies efficiency on the cost of goods sold, reduce operating expenses, increasing assets, and reduce external funding as the primary countermeasure to face difficulties. We concluded that paying attention to external factors and the ability to pay debts were the key to protect the external factor impact.
\end{abstract}

Keywords: debt service coverage ratio, external and internal factors, financial distress, food and beverage firms, two stage least squares (2SLS)

\begin{abstract}
Abstrak: Sub-sektor makanan dan minuman adalah sub-sektor di sektor manufaktur dengan kontribusi dan tingkat pertumbuhan terbesar. Industri makanan dan minuman adalah salah satu sektor penting bagi perekonomian nasional. Pelaku usaha makanan dan minuman di Indonesia menghadapi tantangan bisnis ketika kondisi ekonomi makro melemah. Sehingga perusahaan sub sektor makanan dan minuman sangat rentan mengalami financial distress. Tujuan penelitian Menganalisis dampak perubahan faktor eksternal dan internal terhadap financial distress perusahaan manufaktur subsektor makanan dan minuman. Model financial distress Keuangan Perusahan Sub-sektor Makanan dan Minuman yang menggunakan metode sistem persamaan recursive. Terdapat lima perusahaan yang mengalami kesulitan keuangan dari PT Tiga Pilar Sejahtera Food Tbk (AISA), PT Wilmar Cahaya Indonesia Tbk (CEKA), Indofood Sukses Makmur Tbk (INDF), PT Prashida Aneka Niaga Tbk (PSDN) dan PT Siantar Top Tbk (STTP). Hasil menunjukan kondisi faktor eksternal yang baik tidak cukup untuk meningkat kan rasio debt service coverage sebagai proxy financial distress disarankan perusahan untuk melakukan efisiensi terhadap harga pokok penjualan, menurunkan beban operasi, meningkat kan aset lancar serta menurunkan pendanaan eksternal. Berdasarkan hasil tersebut disimpulkan bahwa perusahaan perlu memperhatikan faktor eksternal dan kemampuan perusahaan untuk membayar hutang.
\end{abstract}

Kata kunci: debt service coverage ratio, faktor eksternal dan internal, financial distress, perusahaan makanan dan minuman, two stage least squares (2SLS)

\footnotetext{
${ }^{1}$ Corresponding author:

Email: raditya_arie@yahoo.com
} 


\section{PENDAHULUAN}

Industri manufaktur merupakan salah satu industri yang penting bagi negara Indonesia karena berperan besar dalam mendorong percepatan pembangunan dan pemerataan ekonomi nasional. Subsektor makanan dan minuman merupakan sub sektor pada sektor manufaktur dengan kontribusi dan tingkat pertumbuhan terbesar. Industri makanan dan minuman (mamin) merupakan salah satu sektor penting bagi perekonomian nasional. Produk Domestik Bruto (PDB) sektor mamin pada tahun 2016 mencapai Rp586,5 triliun atau 6,2\% dari total PDB Nasional senilai Rp9.433 triliun. Selain itu, sektor makanan dan minuman selalu tumbuh di atas pertumbuhan PDB nasional. Pada triwulan III 2017 PDB sub sektor makanan dan minuman tumbuh 9,46\% (YoY) menjadi Rp166,7 triliun, sementara ekonomi Indonesia hanya tumbuh 5,06\%. Sepanjang triwulan I-III 2017, sub sektor mamin tersebut menyumbang $33,78 \%$ PDB sektor pengolahan yang mencapai Rp1.406 triliun dan juga menyumbang 6,42\% PDB nasional yang mencapai Rp7.402 triliun (Gambar 1).

Sementara total penerbitan obligasi tahun 2016 hanya Rp113,69 triliun. Namun, pembiayaan usaha menggunakan kredit bank memberikan risiko yang tinggi bagi pelaku usaha dikarenakan kebijakan bunga kredit yang tidak menentu dan menambah biaya modal perusahaan jika ingin mengajukan pinjaman lebih besar. Fenomena ini dibuktikan oleh meningkatnya non-performing loan (NPL) pada sub sektor makanan dan minuman (Gambar 2).

Sub sektor makanan dan minuman juga merupakan penyumbang perusahaan go public terbanyak yang mengalami delisting di Bursa Efek Indonesia (BEI) untuk sektor manufaktur, yaitu sebesar $25 \%$. Menurut Ramadhani et al. (2009) Perusahaan manufaktur yang diprediksi bangkrut adalah perusahaan yang memiliki kondisi keuangan yang tidak sehat. Perusahaan bisa di delisting dari Bursa Efek Indonesia (BEI) karena perusahaan tersebut berada pada kondisi financial distress atau sedang mengalami kesulitan keuangan (Pranowo, 2010). Menurut Daneshfar et al. (2016) menunjukan semua variabel nilai marginal uang tunai, nilai fleksibilitas, dan rasio leverage, memiliki hubungan langsung dan signifikan terhadap keputusan pengambilan dana. Menurut Ruster (World Bank, 1996) perusahaan dengan nilai DSCR lebih kecil dari 1,20 akan mengalami default atau kegagalan dalam memenuhi kewajiban hutang dan atau bunga. Gambar
3 menunjukan tren nilai DSCR pada perusahan sub sektor makanan dan minuman yang terdaftar di Bursa Efek Indonesia dari tahun 2008 hingga 2017 yang menggambarkan perusahaan yang mengalami financial distress. Berdasarkan Gambar 3, PT. Sekar Bumi Tbk (SKBM) mengalami delisting pada tahun 2009 setelah mengalami financial distress di tahun 2008 dengan nilai -3,4 dan 1,4 dengan rata-rata selama dua tahun -1. Menurut Peter dan Yoseph (2011) kebangkrutan sebagai suatu kegagalan didefinisikan dalam beberapa pengertian, yaitu Kegagalan ekonomi (economic distressed) dan Kegagalan keuangan (financial distressed). Perusahaan yang mengalami financial distress adalah PT. Tiga Pilar Sejahtera Tbk (AISA), PT. Wilmar Cahaya Indonesia Tbk (CEKA), PT. Indofood Sukses Makmur Tbk (INDF), PT. Prashida Aneka Niaga Tbk (PSDN) dan PT. Siantar Top Tbk (STTP). Oleh karena itu, perlu diteliti kondisi financial distress, faktor-faktor internal dan eksternal perusahaan yang memengaruhi kinerja perusahan dan dampaknya terhadap financial distress perusahaan sub sektor Makanan dan Minuman. Financial distress adalah situasi ketika perusahaan tidak memiliki kapasitas untuk memenuhi kewajibannya kepada pihak ketiga (Andrade dan Kaplan, 1998). Arlinda et al. (2015) juga menggunakan DSCR sebagai penentu kondisi financial distress industri telekomunikasi Indonesia. Pada krisis keuangan di Asia yarg terjadi tahun 1997-1998, banyak literatur yang menunjukkan bahwa corporate governance adalah salah satu faktor kunci yang terkait dengan kesulitan keuangan dalam Dwijayanti (2010). Endri (2009) menyatakan bahwa kebangkuratan sebagai kegagalan didefinisikan dalam beberapa arti yaitu: kegagalan ekonomi dan kegagalan keuangan. Kegagalan dalam arti ekonomi berarti bahwa pendapatan perusahaan tidak menutup biayanya sendiri, ini berarti tingkat labanya lebih kecil dari biaya modal atau nilai sekarang dari arus kas perusahaan lebih kecil dari kewajiban. Perusahaan harus dapat memperkirakan kemampuan untuk melunasi utang jangka panjang di masa depan terutama ketika baru ingin meminjam (Grady, 2010).

Berdasarkan latar belakang yang telah diuraikan sebelumnya, perusahaan subsektor makanan dan minuman sangat rentan mengalami financial distress. Hal tersebut terlihat dari pertumbuhan rasio DSC dari tahun 2010-2017 yang menunjukan kondisi penurunan dimana terdapat lima dari delapan perusahaan sampel mengalami financial distress dengan rata-rata rasio DSC dibawah 1,2. Financial distress sendiri adalah 
kondisi dimana hasil operasi perusahaan tidak cukup untuk memenui kewajiban perusahaan (insolvency). Perusahaan manufaktur yang bergerak di makanan dan minuman sangat membutuhkan modal besar untuk menjalankan operasi usaha sehingga pendanaan yang dibutuhkan tidak cukup jika mengandalkan sumber pendanaan internalsehingga memerlukan sumber pendanaan eksternal salah satunya pinjaman ke bank, pihak berelasi ataupun perusahaan pendanaan lainya. Perusahaan yang menggunakan sumber pendanaan eksternal berupa hutang menimbulkan suatu kewajiban yang harus dipenuhi pada periode-periode yang akan datang berupa pembayaran pokok pinjaman beserta bunganya. Apabila pembayaran tersebut tidak dapat dipenuhi maka perusahaan akan mengalami financial distress. Platt dan Platt (2006) menyebutkan bahwa financial distress merupakan tahap penurunan kondisi keuangan yang terjadi sebelum kebangkrutan atau likuidasi. Menurut Munawir (2002) dan Lau (1987) juga menjelaskan bahwa kesulitan keuangan bisa digambarkan di antara dua titik ekstrim yaitu kesulitan likuiditas jangka pendek (yang paling ringan) sampai insolvency (yang paling parah).

Penlitian ini mengacu pada beberapa penelitian terdahulu yang mengkaji tentang pengaruh faktor internal dan faktor eksternal terhadap kondisi financial distress perusahaan dengan menggunakan berbagai metode dan alat pengukur financial distress. Perusahaan yang mengalami kondisi keuangan yang tidak sehat ini karena adanya faktor dari internal dan eksternal perusahaan. Stulpiniene dan Mazure (2013) menggunakan DSCR sebagai salah satu indikator dalam mengukur financial distress of farm di Lituania, Eropa.

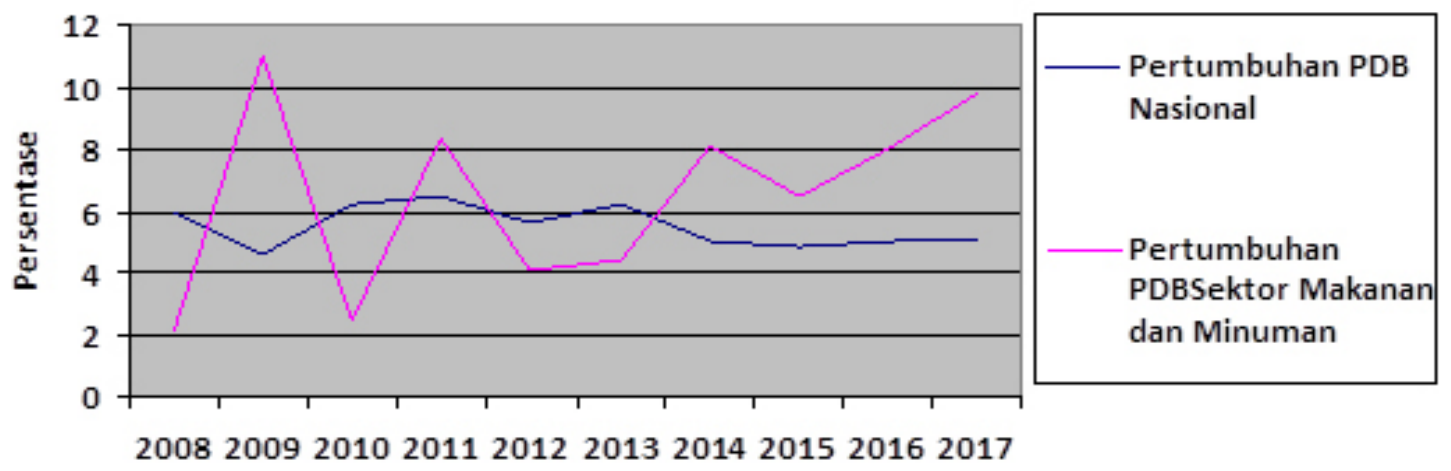

Tahun

Gambar 1. Pertumbuhan industri makanan dan minuman terhadap PDB nasional Tahun 2008 -2012 (BPS, 2018)

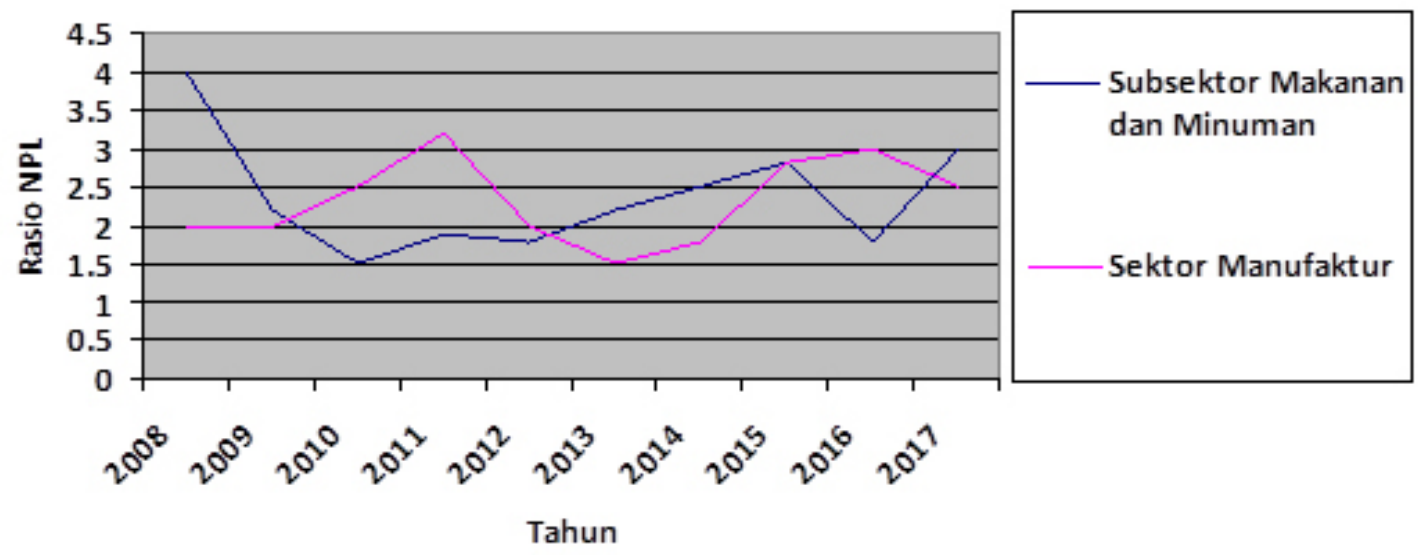

Gambar 2. Perkembangan NPL kredit subsektor makanan dan minuman tahun 2008- 2017 (BI, 2017) 
Fitszpatrick (2004) melakukan penelitian mengenai Kajian empiris mengenaik dinamika financial distress ditemukan bahwa kondisi financial distress didasarkan tiga hal yaitu ukuran perusahaan, jumlah hutang dan standard deviasi dari aset perusahaan. Perbedaan dengan penelitian sebelumnya adalah melihat faktor eksternal dari kondisi makro ekonomi. Alifiah (2013) Prediction of Financial Distress Companies in the trading and services sector in Malaysia using macroeconomics variables. Variable independen yang digunakan untuk memprediksi financial distress di perusahaan sector trading dan service adalah DER, Total Aset Turnover Ratio, working Capital Ratio and Base Lending rate. Perbedaan dengan penelitian sebelumnya adalah menggunakan rasio $\mathrm{CR}$ sebagai parameter yang berpengaruh terhadap DSC ratio. Pada penelitian Kadir (2014) analisis laba dan arus kas dalam memprediksi financial distress pada perusahaan manufakatur yang terdaftar di bursa efek Indonesia, penelitian ini menggunakan variable yang sama, yaitu laba sebagai penentu financial distress. Sudarsanam and Lai (2001) dalam penelitian Corporate Financial Distress and Turnaround Strategies: An Empirical Analysis menyatakan perlu adanya restrukturisasi pendanaan pada persuahaan pasca mengalami financial distress. Berdasarkan perumusan masalah maka tujuan dilakukannya penelitian ini adalah (1) menganalisis kondisi financial distress perusahaan; (2) menganalisis faktor-faktor yang memengaruhi financial distress perusahaan; (3) menganalisis dampak perubahan faktor eksternal dan internal terhadap financial distress perusahaan manufaktur subsektor makanan dan minuman.

\section{METODE PENELITIAN}

Penelitian menggunakan pendekatan kuantitatif yang mendeskripsikan suatu fakta atau fenomena secara statistik dan menunjukan hubungan antara fakta tersebut dengan menggunakan model ekonometrika. Analisis yang digunakan untuk tujuan pertama adalah deskriptif tabulasi, tujuan kedua Model Financial Distress perusahaan manufaktur subsektor makanan dan minuman, dan tujuan ketiga skenario dampak simulasi faktor eksternal dan internal perusahaan manufaktur subsektor makanan dan minuman. Dalam penelitian ini hanya menggunakan data sekunder seperti laporan keuangan perusahaan sampel, produk domestik bruto Indonesia, inflasi, pengeluaran kebutuhan rumah tangga selama tahun 2008-2017. Data tersebut diperoleh melalui metode dokumentasi dari lembaga-lembaga terkait seperti Bank Indonesia, Otoritas Jasa Keuangan, Badan Pusat Statistik dan lembaga terkait lainya. Selanjutnya, metode estimasi model yang digunakan adalah 2SLS (Two Stage Least Square). Hasil identifikasi model adalah over identified dan model dapat diestimasi menggunakan metode 2SLS menggunakan software Statistical Analysis System/ Econometric Time Series (SAS/ETS) versi 9.4.
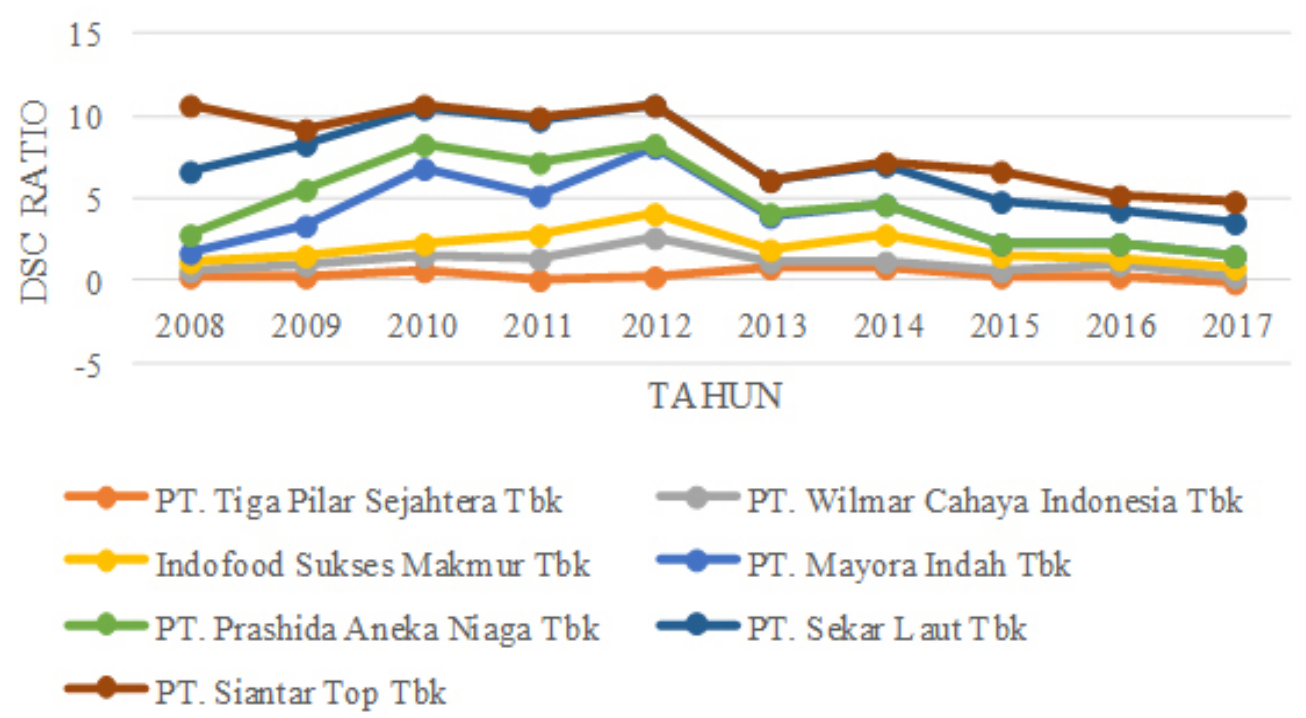

$\longrightarrow$ PT. Sekar L aut Tbk

Gambar 3. Debt Service Coverage Ratio perusahaan makanan dan minuman yang terdaftar di Bursa Efek Indonesia periode tahun 2008-2017 (BEI, 2017) 
Spesifikasi Model

Model Financial Distress Keuangan Perusahan Subsektor Makanan dan Minuman yang dibangun dalam bentuk sistem persamaan recursive. Tahapan spesifikasi model terdiri atas: (1) penentuan variabel dependen (dependent variable) dan variabel penjelas (explanatory variable) yang digunakan dalam persamaan, (2) harapan secara teoritis mengenai tanda dan besaran parameter (sign dan magnetitude) estimasi dari setiap variabel dalam persamaan, dan (3) menentukan bentuk matematik setiap persamaan menurut Koutsoyiannis (1977) dan Intriligator (1978).
Ekonometrik merupakah hasil dari pandangan tertentu pada aturan ekonomi, terdari dari penerapan statistik matekmatika ke data ekonomi untuk memberikan dukungan empiris kepada model yang dibangun oleh ekonomi matematika dan memperoleh hasil numerik (Tintner, 1968). Ekonometrika dapat didefiniskan sebagai analisis kuantitatif ekonomi actual, fenomena berdasarkan perkembangan bersamaan teori dan observasi, terkait dengan metode inferensi yang tepat (Samulelson, 1954). Diagram keterkaitan antar variabel dalam model fleksibilitas keuangan perusahaan subsektor makanan dan minuman selengkapnya pada Gambar 4.

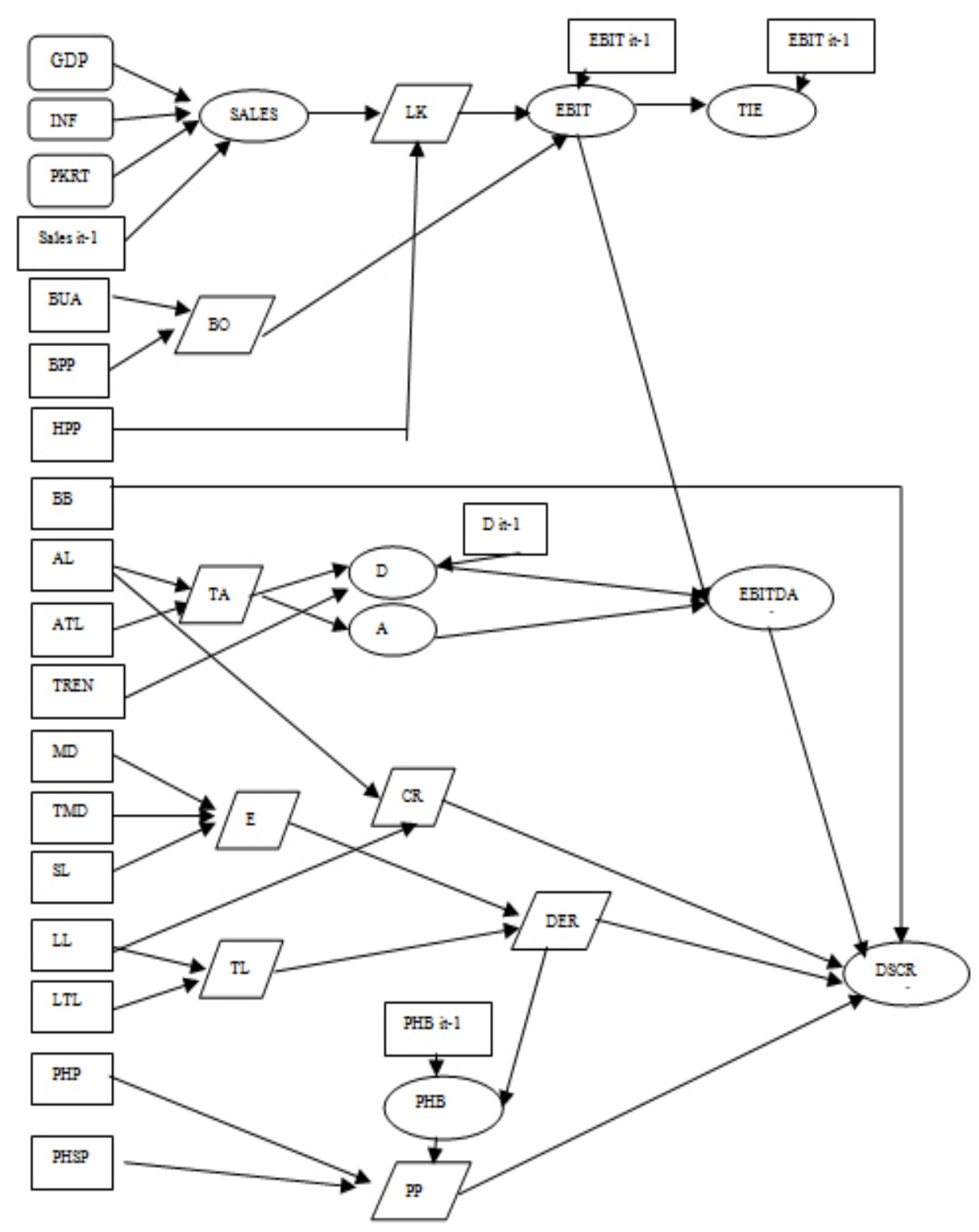

Gambar 4. Diagram keterkaitan antar variabel dalam model fleksibilitas keuangan perusahaan subsektor makanan dan Minuman 
Skenario Simulasi

Skenario simulasi dilakukan untuk melihat dampak faktor internal (harga pokok penjualan, beban umum dan administrasi, dan beban penjualan dan pemasaran, total aset lancar, prinscipal payment) dan eksternal (GDP Indonesia, pengeluaran konsumsi rumah tangga dan inflasi) terhadap kondisi financial distress keuangan perusahaan subsektor makanan dan minuman. Penentuan angka perubahan pada simulasi faktor eksternal didasari oleh data historis Indonesia. Simulasi yang dilakukan terhadap perusahaan yang mengalami financial distress yang dilakukan adalah:

S1: GDP Indonesia meningkat 4\%, pengeluaran konsumsi Rumah Tangga meningkat sebesar $5 \%$,harga pokok penjualan turun3\%, beban umum dan administrasi dan beban penjualan dan pemasaran turun $5 \%$

S2: GDP Indonesia meningkat 4\%, pengeluaran konsumsi Rumah Tangga meningkat sebesar $5 \%$, dan inflasi meningkat $3.5 \%$ harga pokok penjualanturun $3 \%$, beban umum dan administrasi dan beban penjualan dan pemasaran turun 5\%

S3: GDP Indonesia meningkat 4\%, pengeluaran konsumsi Rumah Tangga meningkat sebesar $5 \%$, dan inflasi meningkat $3.5 \%$ harga pokok penjualanturun $3 \%$, beban umum dan administrasi dan beban penjualan dan pemasaran turun $5 \%$ dan meningkatkan total aset lancar $10 \%$

S4: GDP Indonesia meningkat $4 \%$, pengeluaran konsumsi Rumah Tangga meningkat sebesar
$5 \%$, dan inflasi meningkat $3.5 \%$ harga pokok penjualan turun $3 \%$, bebanumum danadministrasi dan beban penjualan dan pemasaran turun 5\% dan meningkatkan total aset lancar $10 \%$ dan menurunkan pendanaan eksternal 10\%

Berdasarkan perumusan masalah dan tujuan penelitian yang telah dijelaskan bahwa perusahaan subsektor makanan dan minuman yang rentan mengalami kondisi financial distress, dimana kondisi tahap penurunan kondisi keuangan yang terjadi pada perusahaan sebelum kebangkrutan maka kerangka pemikiran disajikan pada Gambar 5. Tujuan penelitian untuk menganalisis kondisi financial distress, faktor-faktor yang memengaruhi kinerja perusahaan, dan dampak faktor eksternal dan internal terhadap financial distress keuangan perusahaan subsektor makanan dan minuman yang terdaftar di Bursa Efek Indonesia periode tahun 2008-2017. Pemilihan faktor eksternal didasari oleh faktor-faktor yang memengaruhi profitabilitas karena semaking tinggi profitabilitas maka semakin tinggi tingkat keberhasilan atau kegagalan perusahaan selama jangka waktu tertentu (Atmini dan Wuryan, 2005). Menurut Carliss et al. (1993) ketika bisnis perusahaan memburuk ke titik di mana tidak dapat memenuhi kewajiban keuangannya, perusahaan dikatakan telah memasuki keadaan kesulitan keuangan. Biaya internal umum lebih dipilih karena biaya penggunaan sumber ini lebih rendah dari pada yang lain dan kemudian sampai pada penggunaan hutang sebelum mengeluarkan ekuitas baru (Dai, 2017).

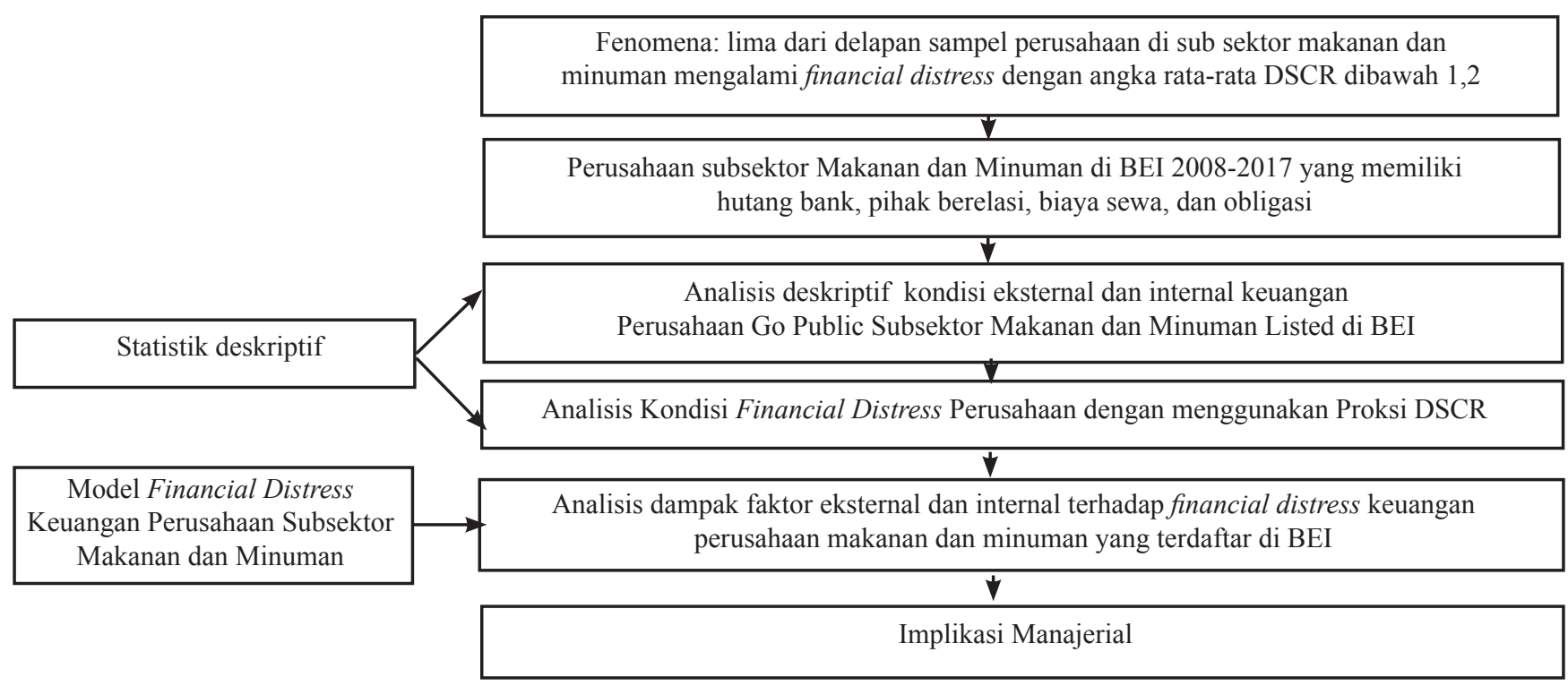

Gambar 5. Kerangka pemikiran 


\section{HASIL}

\section{Kondisi Financial Distress Keuangan Perusahaan Subsektor Makanan dan Minuman}

Perusahaan yang mengalami financial distress adalah PT Tiga Pilar Sejahtera Food Tbk (AISA), Wilmar Cahaya Indonesia Tbk (CEKA), Indofood Sukses Makmur Tbk (INDF), Prashida Aneka Niaga Tbk (PSDN) dan Siantar Top Tbk (STTP) perusahaan tersebut mempunyai nilai DSCR di bawah 1.20. Perusahaan yang tidak mengalami financial distress keuangan adalah PT Mayora Indah Tbk (MYOR) dan Ultrajaya Milk Industry and Trading Company Tbk (ULTJ) perusahaan tersebut memiliki nilai DSCR di atas 1,20.

\section{Faktor-faktor yang Memengaruhi Kinerja Perusahaan subsektor makanan dan minuman}

Keragaan umum hasil pendugaan model

Model dalam financial distress sub sektor makanan dan minuman penelitian dibangun dari 16 persamaan, terdiri dari 8 persamaan perilaku dan 8 persamaan identitas. Model tersebut sudah melalui beberapa tahapan respesifikasi model. Berdasarkan hasil estimasi dapat dijelaskan secara umum semua variabel penjelas yang dimasukkan kedalam persamaan perilaku mempunyai tanda yang sesuai dengan harapan, khususnya dilihat dari teori ekonomi. Kriteria statistik yang umum digunakan dalam mengevaluasi hasil estimasi Model financial distress sebesar $87,5 \%$ persamaan perilaku memiliki koefisien determinasi (R2) di atas 0,50 dan $12,5 \%$ persamaan yang memiliki nilai R2 dibawah 0,50 . Persamaan perilaku yang memiliki koefisien determinasi (R2) terbesar terdapat pada persamaan earning before interest and tax sebesar 0,99 dan nilai terkecil terdapat pada persamaan debt service coverage ratio (DSCR) 0,478.

Hasil validasi Model

Hasil validsai model fleksibilitas keuangan perusahaan subsektor makanan dan minuman disajikan pada Tabel 1. Berdasarakan Tabel 1 hasil validasi model Financial Distress perusahaan subsektor makanan dan minuman menunjukan $100 \%$ dari variabel mempunyai nilai U-Theil dibawah 50\%. Hal ini menunjukan bahwa selama periode pengamatan, yakni periode tahun 2008-2017 nilai prediksi variable endogen cukup baik digunakan untuk simulasi model.

Tabel 1.Hasil validasi model financial distress perusahaan subsektor makanan dan minuman

\begin{tabular}{llcc}
\hline Notasi & Variabel & Satuan & U-Theil \\
\hline SALES & Penjualan makanan dan minuman & Juta Rp & 0,0295 \\
LK & Laba kotor & Juta Rp & 0,1060 \\
BO & Beban operasi & Juta Rp & 0,0010 \\
EBIT & Earning before interest and tax & Juta Rp & 0,1520 \\
TIE & Time interest earning & Rasio & 0,0943 \\
TA & Total asset & Juta Rp & 0,0001 \\
D & Depresiasi & Juta Rp & 0,0487 \\
A & Amortisasi & Juta Rp & 0,2599 \\
EBITDA & Earning before interest tax depreciation and amortization & Juta Rp & 0,1221 \\
TL & Total Liabilitas & Juta Rp & 0,0013 \\
E & Ekuitas & Juta Rp & 0,0837 \\
CR & Current Ratio & Rasio & 0 \\
DER & Debt Equity Ratio & Rasio & 0,0646 \\
PHB & Pembayaran Hutang Bank & Juta Rp & 0,3224 \\
PP & Principal payment & Juta Rp & 0,3060 \\
DSCR & Debt service coverage ratio & Rasio & 0,3900 \\
\hline
\end{tabular}




\section{Hasil Skenario Simulasi Perubahan Faktor Eksternal dan Internal Model}

Simulasi model financial distress perusahaan subsektor makanan dan minuman di validasi, langkah selanjutnya adalah scenario dampak simuasi. Simulasi bertujuan untuk mengetahui perubahan dampak yang terjadi pada debt service service coverage ratio. Berikut disajikan alternative dampak scenario simulasi faktor eksternal dan faktor internal terhadap financial distress perusahaan subsektor Makanan dan Minuman

\section{Simulasi 1}

Produk domestik bruto Indonesia meningkat sebesar $4 \%$, pengeluaran konsumsi rumah tangga meningkat $5 \%$, harga pokok penjualan turun sebesar $3 \%$, beban umum administrasi dan beban pokok penjualan turun sebesar 5\%. Kondisi faktor eksternal yang baik berdampak terhadap meningkatnya jumlah penjualan makanan dan minuman sebesar Rp11.233 triliun tetapi hasil dari keadaan ekonomi yang baik tidak cukup untuk meningkat kan nilai debt service coverage ratio maka perusahaan perlu melakukan antisipasi faktor internal sehingga meningkatkan laba kotor sebesar Rp3.396 triliun, beban operasi menurun menjadi Rp1.458 triliun, earning before interest and tax meningkat menjadi Rp1.760 triliun dan earning before interest tax depreciation and amortsation meningkat menjadi Rp2.102 triliun dan debt service coverage ratio perusahaan makanan dan minuman meningkat menjadi 1,20

\section{Simulasi 2}

Skenario simulasi 2 terhadap 7 sampel perusahaan makanan dan minuman yaitu pada kondisifaktor eksternal produk domestik Indonesia meningkat 4\%, inflasi naik 3,5\% dan pengluaran konsumsi rumah tangga untuk makanan dan meningkat 5\% diantisipasi dengan harga pokok penjualan turun $3 \%$, beban umum administrasi dan beban penjualan dan pemasaran turun 5\% sehingga berhasil meningkatkan sales menjadi Rp11.201 triliun dan meningkatkan earning before interes and tax menjadi Rp1.740 triliun dan earning before interest tax depreciation and amortization meningkat menjadi Rp2.082 triliun dan debt service coverage ratio perusahaan makanan minuman meningkat menjadi 1.2025 .
Simulasi 3

PDB Indonesia meningkat 4\%, pengeluaran konsumsi Rumah Tangga meningkat sebesar 5\%, dan inflasi meningkat $3,5 \%$ harga pokok penjualan turun $3 \%$, beban umum dan administrasi dan beban penjualan dan pemasaran turun 5\% dan meningkatkan total aset lancar $10 \%$ sehingga berdampak terhadap meningkatnya jumlah penjualan makanan dan minuman sebesar Rp11.201 triliun, meningkatnya laba kotor sebesar Rp3.365 triliun, beban operasi menurun menjadi Rp1.458 triliun, earning before interest and tax meningkat menjadi Rp1.740 triliun dan earning before interest tax depreciation and amortsation meningkat menjadi Rp2.090 triliun, meningkatkan total asset lancar pada simulasi berguna untuk meningkatkan cadangan kas pada arus keuangan untuk membayar hutang-hutang yang jatuh tempo sehingga debt service coverage ratio perusahaan makanan dan minuman meningkat menjadi 1,22.

\section{Simulasi 4}

Skenario simulasi 4, yaitu PDB Indonesia meningkat sebesar 4\%, pengeluaran konsumsi rumah tangga meningkat sebesar 5\%, dan inflasi meningkat 3.5\% diantisipasi dengan harga pokok penjualan turun3\%, beban umum dan administrasi dan beban penjualan dan pemasaran turun $5 \%$ dan meningkatkan total aset lancar $10 \%$ dan menurunkan pendanaan eksternal $10 \%$. Pada kondisi simulasi 4 faktor eksternal yang kurang baik berdampak terhadap menurunnya jumlah penjualan makanan dan minuman sebesar Rp11,201. triliun di antisipasi dengan faktor internal sehingga laba kotor sebesar Rp3.365 triliun beban operasi menurun menjadi Rp1.458 triliun, earning before interest and tax meningkat menjadi Rp1.740 triliun dan earning before interest tax depreciation and amortsation meningkat menjadi Rp2.090 triliun. Penambahan simulasi pengurangan pendanaan eksternal mengakibatkan menurun nya pokok pinjaman dan beban bunga sehingga debt service coverage ratio perusahaan makanan dan minuman meningkat menjadi 1,22.

\section{Implikasi Manajerial}

Kondisi faktor eksternal yang baik tidak cukup untuk meningkatkan rasio debt service coverage sebagai proxy financial distress disarankan perusahan untuk melakukan efisiensi terhadap harga pokok penjualan melalui pemilihan bahan baku dengan harga yang 
lebih kompetitif, menurunkan beban operasi seperti melakukan pengurangan pada promosi penjualan, meningkat kan aset lancar yang bisa dilakukan melalui penagihan piutang yang baik serta menurunkan pendanaan eksternal sehingga dapat meningkatkan rasio debt service coverage ratio. Bagi perusahaan perlu dilakukan kontrol atau batasan penentu besarnya hutang kepada besarnya debt service coverage ratio (DSCR) yang setiap saat harus lebih besar dari 1,2. Hal ini tidak hanya berupa hutang bank, tetapi juga termasuk besarnya kewajiban perusahaan pada waktu penerbitan obligasi. Pemerintah perlu menjaga kondisi perekonomian Indonesia seperti produk domestik bruto Indonesia, inflasi, dan pengeluaran rumah tangga.

\section{KESIMPULAN DAN SARAN}

\section{Kesimpulan}

Dari 7 sampel perusahaan subsektor makanan dan minuman, terdapat dua perusahaan yang tidak mengalami financial distress, yaitu PT Mayora Indah Tbk (MYOR) dan PT Sekar Laut Tbk (SKLT). Sedangkan lima perusahaan yang mengalami financial distress yaitu PT Tiga Pilar Sejahtera Food Tbk (AISA), PT Wilmar Cahaya Indonesia Tbk (CEKA), PT Indofood Sukses Makmur Tbk (INDF), PT Prashida Aneka Niaga Tbk (PSDN) dan PT Siantar Top Tbk (STTP). Debt service coverage ratio dipengaruhi variabel current ratio, principal payment, debt to equity ratio, Earning before interest tax depreciation and amortization dan beban bunga. Variabel yang berpengaruh signifikan adalah EBITDA, beban bunga dan principal payment.

Dampak faktor eksternal dan internal terhadap financial distress perusahaan subsektor makanan dan minuman. jika kondisi ekstenal produk domestik bruto Indonesia dan pengeluaran kebutuhan rumah tangga dan inflasi meningkat maka dapat diantisipasi dengan faktor internal seperti menurunkan harga pokok penjualan, beban umum administrasi,beban penjualan dan pemasaran maka berdampak terhadap peningkatan debt service coverage ratio perusahaan sehingga perusahaan tidak mengalami financial distress.

\section{Saran}

Memasukkan variabel volume produksi dan stok inventory sebagai persamaan structural untuk model persamaan total penjualan. Memasukan variabel harga produk per masing-masing perusahaan. Dengan demikian, akan dapat dianalisis dampak perubahan harga produk dan volume produksi dan stok terhadap kondisi financial distress perusahaan subsektor makanan dan minuman.

\section{DAFTAR PUSTAKA}

Alifiah MN. 2013. Prediction of financial distress companies in the trading and services sector in Malaysia using macroeconomic variables. Jurnal Department of Accounting and Finance 64(1):85-91.

Andrade, Kaplan. 1998. How costly is financial (not economic) distress? evidence from highly leveraged transactions that became distressed. Jurnal of Finance 53(2) : 1443-1493.https://doi. org/10.1111/0022-1082.00062.

Arlinda, Achsani NA, Saptono IT. 2015. Impact of merger and acquisition on financial performance and financial distress: empirical evidence from Indonesian telecommunication industry. European Journal of Business and Management 7(25):125-133.

Atmini S, Wuryan A. 2005. Manfaat laba dan arus kas untuk memprediksi kondisi financial distress pada perusahaan textile mill products dan apparel and other textile products yang terdaftar di Bursa Efek Jakarta. Jurnal Nasional Akuntansi 8:1516.

Carlis Y, Baldwin, Mason PS. 1993. The resolution of claims in financial distress: the case of Massey Ferguson. Journal of Finance 38(2): 505-516. https://doi.org/10.1111/j.1540-6261.1983. tb02258.x.

Dai TB, 2017. The relationship of the capital structure and financial performance: empirical evidence of listed banks in Thailand. Europe Journal of Accounting Auditing and Finance Research 5(5): 18-28

Daneshfar S, Tabriz AA, Mohagheghzadeh F. 2016. The effect of financial flexibility companies listed on the stock exchange capital structure decisions. Jurnal of Novel Applied Sciences 5(6): 213-218.

Dwijayanti PF. 2010. Penyebab, dampak, dan prediksi dari financial distress serta solusi untuk menagati financial distress. Jurnal Akuntansi Kontemporer 2(2): 191-205.

Endri. 2009. Prediksi kebangkrutan bank untuk 
menghadapi dan mengelola perubahan lingkungan: analisis model Altman Z-Score. Jurnal Perbanas Quarterly Review 2(1): 34-50.

Fitszpatrick. 2004. An empirical investigation of dynamics of financial distress [disertasi]. New York: Faculty of the Graduate School, State University of New York.

Kadir A. 2014. Analisis laba dan arus kas dalam memprediksi financial distress pada perusahaan manufaktur di bursa efek Indonesia. Jurnal Ilmu Sosial 6(2): 191-198.

Lau, A. H. 1987. A five state financial distress prediction model. Journal of Accounting Research 25: 127138. https://doi.org/10.2307/2491262.

Munawir S. 2004. Analisis Laporan Keuangan, Edisi Ke-4, Liberty, Yogyakarta. Ikatan Akuntansi Indonesia (IAI) 2004. Jakarta: Salemba Empat.

Grady JT. 2010. Debt service coverage ratio two views are better than one. The RMA Journal 3(2):15260.

Koutsoyiannis A. 1977. Theory of Econometrics: An Introductory Exposition of Econometrics Methods. Second Edition. The MacMillan Press Ltd, London.

Peter, Yosep. 2011. Analisis kebangkrutan dengan metode z-score altman, springate dan zmijewski pada PT Indofood Sukses Makmur Tbk periode 2005-2009. Akurat Jurnal Ilmiah Akuntansi 4(2): 23-29.
Platt H, Platt MB. 2002. Predicting financial distres. Journal of Financial Service Professionals. 56(2): 12-15.

Pranowo K. 2010. Corporate financial distres perusahaan publik (non financial companies) di indonesia [Disertasi]. Bogor: Institut Pertanian Bogor.

Ramadhani, Suci A, Niki L. 2009. Perbandingan analisis prediksi kebangkrutan menggunakan model Altman pertama, Altman revisi, dan Altman modifikasi dengan ukuran dan umur perusahaan sebagai variabel penjelas. Jurnal Siasat Bisnis 13(1): 15-28. https://doi.org/10.20885/jsb. vol13.iss1.art2.

Ruster J. 1996. Mitigating commercial risks in project finance. Public Policy for Private Sector Series Note No.69.

Sudarsanam S, Lai J. 2001. Corporate financial distress and turnover strategies: an emperical analysis. British Jurnal of Management 12(3): 183-189. https://doi.org/10.1111/1467-8551.00193.

Stulpiniene V, Mazure G. 2013. Finding financial distress predictor of farms. Rural Development 6(1): 383-388

World Bank. 2016. GDP Growth China. http://data. worldbank.org/indicator/NY.GDP.MKTP. KD.ZG?locations=CN [20 Desember 2016]. 